\title{
PENGARUH CREATIVITY, PROACTIVE PERSONALITY, DAN ENTREPRENEURIAL ALERTNESS TERHADAP INTENSI BERWIRAUSAHA PADA MAHASISWA
}

\author{
${ }^{1}$ Willison dan ${ }^{2}$ Rodhiah \\ Program Studi Manajemen Fakultas Ekonomi Universitas Tarumanagara, Jakarta \\ Willison.115160419@stu.untar.ac.id
}

\begin{abstract}
The purpose of this study was to see the influence of creativity, proactive personality, and entrepreneurship on student entrepreneurial intentions. The sampling technique is non probability sampling. The data technique uses a questionnaire with the help of google form. The number of samples used was 99 respondents. The analysis technique uses multiple regression analysis with $t$ test and the coefficient of determination. The data analysis tool used is the assistance of the Statistics Product and Service solutions (SPSS) program. The results showed that Creativity, Proactive Personality and Entrepreneurial Awareness had a positive and significant effect on student entrepreneurial intentions.
\end{abstract}

Keywords: Creativity, Proactive Personality, Entrepreneurial Alertness, Entrepreneurial Intention.

Abstrak: Tujuan dari penelitian ini untuk mengetahui pengaruh Creativity, Proactive Personality, dan Entrepreneurial Alertness terhadap intensi berwirausah pada mahasiswa. Teknik pengambilan sampel yaitu non probability sampling. Teknik pengumpulan data menggunakan kuisioner dengan bantuan google form. Jumlah sampel yang digunakan adalah 99 responden. Teknik analisis ini menggunakan analisis regresi berganda dengan uji t dan koefisien determinasi. Alat analisis data yang digunakan adalah dengan bantuan program Statistical Product and Service solutions (SPSS). Hasil penelitian menunjukan bahwa Creativity, Proactive Personality dan Entrepreneurial Alertness berpengaruh positif dan signifikan terhadap intensi berwirausaha pada mahasiswa.

Kata Kunci: Creativity, Proactive Personality, Entrepreneurial Alertness, Intensi Berwirausaha.

\section{LATAR BELAKANG}

Wirausaha saat ini menjadi peranan yang sangat penting dalam pertumbuhan dan pembangunan dalam meningkatkan perekonomian Indonesia. Apabila angka pengganguran menurun dapat memberikan dampak positif terhadap pendapatan negara Indonesia. Wirausaha merupaka suatu proses inovasi dan kreatif dalam mengembangkan suatu produk atau jasa yang bermanfaat bagi masyarakat. Kewirausahaan menjadi topik yang hangat di negara industry . Dalam pembinaan dan pengembangan kewirausahaan bisa didapat melalui pelatihan dan Pendidikan. Pendidikan kewirausahaan juga mengalami peningkatan di beberapa perguruan tinggi yang terdapat di Indonesia.

Pendidikan kewirausahaan dapat dipengaruhi oleh banyak hal seperti keinginan belajar yang dapat ditelusuri dan dilihat dari peranan perguruan tinggi. Peranan perguruan tinggi dalam mengembangkan niat berwirausaha dapat digali pada beberapa factor pada perilaku 
kewirausahaan.( Zimmerer 2012). Penelitian tersebut menjelaskan bahwan niat berwirausaha dapat diliat melalui Pendidikan kewirausahaan yang dipengaruhi oleh minat dan sikap dalam berwirausaha. Disini mahasiswa atau lulusan dari perguruan tinggi diharapkan bisa menjawab permasalahan tersebut dalam memperkecil angka penganguran dan mampu menjadi wirausaha.

Seiring perkembangan zaman dan waktu persaingan di dalam dunia bisnis sangat membuat seorang wirausaha untuk menciptakan produk atau jasa yang dapat diterima oleh masyarakat. Mahsiswa merupakan calon lulusan perguruan tinggi yang perlu dibekali dan didorong niat dalam berwirausaha ( Entreprenurial Intention). Intention Entrepreneurial merupakan kebulatan pada tekad seseorang untuk menjadi seorang wirausaha. Lee, S.H. \& Wong (2004) menyatakan bahwa niat dalam berwirausaha adalah suatu komitmen, sikap, kemampuan dan tindakan yang direncanakan dalam melakukan perilaku terhadap kewirausahaan untuk meciptakan sesuatu yang baru.

Terdapat banyak hal yang dapat mempengaruhi intensi berwirausaha seseorang. Salah satunya menurut sebuah penelitian Rifqi Hapsah dan Siti Ina Savira (2015) menunjukan bahwa kreativitas berpengaruh positif terhadap niat berwirausaha. Kreativitas adalah elemen kunci pada proses kewirausahaan. Kreativitas sangat berpengaruh dalam membuat jasa atau produk yang ingin diciptakan. Kreativitas adalah kemampuan dalam memproduksi hal hal atau gagasan gagasan baru yang berwujud imajinasi atau pola pola yang dihubungkan pada saat ini atau yang sudah ada. Munandar (2009). Santrock (2014) menerangkan bahwa Ide kreatif muncul dari sebuah interaksi disekitarnya atau muncul secara tiba tiba tanpa dipikirkan. Dengan adanya sebuah kreativitas dapat memberikan suatu kebaikan dalam dalam bekerja.

Selain Kreativitas, Proactive Personality juga mempengaruhi suatu usaha. Untuk mengembangkan sutu usaha seorang wirausah harus mempunyai keahlian atau kemampuan proaktif dalam usahanya. Keahlian proaktif merupakan suatu keahlian atau kemampuan dalam membuat kesempatan baru, meramalkan permintaan di masa sekarang maupun di masa depan sehingga dapat meminpin pasar yang dibutuhkan konsumen. Covey (2010) seseorang yang memiliki sikap proaktif mampu memberi stimulus atau jeda dalam menentukan keputusan terhadap respon yang ditimbulkan. Sikap proaktif yang dimiliki manusia selalu memberi tujuan, berorientasi di masa depan dan bergerak maju secara internal yg dimiliki dalam diri nya sendiri. Sikap Proaktif sangat penting bagi seseorang apabila menghadapi tantangan. Dalam membangun sebuah usaha wirausaha juga harus memperhatikan Entrepreneur alertness untuk mengurangi resiko yang akan terjadi. Aurilia Triani Aryaningtyas (2018) Penelitian menunjukan kepribadian proaktif berpengaruh positif dan signifikan terhadap niat berwirausaha.

Entrepreneurial alertness adalah suatu sikap waspada terhadap usaha yang dilakukan wirausaha. Entrepreneurial alertness mempengaruhi beberapa kepribadian dalam memulai usaha yaitu pengalaman dan pengetahuan dalam bertindak. Tang, Kacmar dan Busenitz (2012) mengatakan bahwa tahap awal seorang wirausaha harus mencari informasi dalam mengurangi resiko dan harus mempunyai sikap kewaspadaan (entrepreneurial alertness). Sikap waspada ini adalah kesiapan dalam melihat peluang pasar yang sering dilihat oleh banyak orang sehingga seorang wirausaha mampu memberikan kekurangan yang tidak tersedia pada pasar. Entrepreneuer alertness dapat dipengaruhi oleh pengetahuan, pengalaman, jejaring social dan kepribadian tertentu. Hu, Wang, Zhang dan Bin (2018) penelitian menunjukan bahwa kewaspadan kewirausahaan berpengaruh positif terhadap niat berwirausaha.

Berdasarkan latar belakang diatas, penulis tertarik untuk melakukan penelitian tentang factor yang mempengaruhi intensi dalam berwirausaha. Untuk itu judul yang ingin diteliti penulis adalah Pengaruh Creativity, Proactive Personality, dan Entrepreneurial Alertness terhadap intensi Berwirausaha pada mahasiswa. 


\section{KAJIAN TEORI}

\section{Creativity}

Dufays (2014) mengatakan bahwa kreativitas umumnya dianggap sebagai langkah awal dalam berwirausaha. Pentingnya kreativitas dapat diartikan sebagai solusi atau ide dalam memecahkan masalah. Kreativitas dianggap memberikan dasar pengetahuan untuk menciptakan produk atau dapat mengkreasikan sesuatu hal yang baru. Baldacchino (2008) mengatakan orang yang mampu berpikir kreatif dan inovatif merupakan kunci kesuksesan yang dapat dijadikan informasi atau peluang untuk menciptakan sesuatu yang berbeda. Kreativitas merupakan kemampuan dalam berpikir yang dapat mengembangkan atau menemukan ide ide yang digunakan untuk menciptakan persaingan dalam berwirausaha. Rodhiah dkk (2021) Kreativitas sangat penting dalam menciptakan produk baru untuk bersaing dalam kesuksesan.

Berdasarkan defenisi para ahli diatas bahwan kreativitas adalah sebuah ide atau cara berpikir dalam menciptakan sesuatu hal baru untuk memenuhi pasar atau kebutuhan masyarakat yang belum ada pada saat ini.

\section{Proactive Personality}

Crant, 2000 Bakker el al (2012) Kepribadian proaktif adalah karakteristik kepribadian yang stabil yang dapat menunjukan inisiatif, mengidentifikasikan dan tekun dalam melihat peluang atau memberikan perubahan. Kepribadian proaktif tindakan untuk mempengaruhi diri secara aktif dari dalam diri sendiri atau lingkungan sekitar . Mustafa et al (2016) mengatakan bahwa kepribadian proaktif mempunyai peran penting dalam berwirausaha. Kepribadian proaktif adalah sifat individu yang dimiliki seseorang secara komparatif dan dapat mengidentifikasikan perbedaan orang dalam melakukan suatu tindakan.

Berdasarkan definisi para ahli diatas Proactive Personality adalah sebuat inisiatif , pengetuhuan, kemampuan serta berani dan bertanggung jawab atas apa yang dilakukan.

\section{Entrepreneurial Alertness}

Valliere (2013) mengatakan bahwa kewaspadaan berwirausaha dapat dikemukan dengan pengambilan akal sehat melalui rangsangan baik yang berasal dari dalam atau dari luar lingkungan. Kewaspadaan berwirausaha juga dapat dikatakan modal dalam membuka usaha karena kita dapat mengetahui dan mendapatkan informasi baru mengenai kekurangan yang ada di pasar. Tang dkk (2012) mengatakan bahwa terdapat 3 elemen dalam kewaspadaan berwirausaha yaitu yang pertama asosiasi dan koneksi informasi dalam kebutuhan pasar, evaluasi dan penilaian peluang dan yang terakhir ialah pemindaian dan mencari informasi baru yang menjadi kekurangan atau yang belum tersedia untuk menjangkau keinginan konsumen.

Berdasarkan defenisi para ahli diatas Entrepreneurial Alertness adalah dimana setiap orang yang ingin berwirausaha harus mempunyai sikap waspada dalam membangun dan mengembangkan suatu usaha dengan cara mengenali, mempelajari, mengevaluasi dan menggabungkan informasi yang didapat.

\section{Intensi Berwirausaha}

Intensi merupakan kesiapan niat seseorang untuk melakukan tindakan atau perbuatan untuk menciptakan sesuatu yang baru atau suatu perilaku tertentu Wijaya (2007). Dalam melakukan kegiatan berwirausaha harus didasari pada minat berwirausaha secara konsisten. Artinya setiap orang yang sudah memutuskan berwirausaha harus memiliki niat sebagai modal awal dalam berwirausaha. Lo Choi Tung (2011) Intensi berwirausaha merupakan sikap seseorang antara kewirausahaan dengan perilaku kewirausahaan. 
Berdasarkan para ahli diatas intensi berwirausaha merupakan niat seseorang untuk berwirausaha. Niat berwirausaha merupakan factor penting dalam meningkatkan perilaku kewirausahaan.

\section{Kaitan Kreativitas terhadap intensi berwirausaha,}

Fatmawati (2013) Kreativitas dalam intensi berwirausaha bisa berkembang dengan adanya ide ide kreatif atau mempunyai inovasi baru dalam membentuk atau membuat produk atau jasa.

Suryana (2006) Kewirausahaan merupakan suatu proses inovasi dan penerapan kreativitas dalam mencari peluang dan memecahkan masalah untuk memperbaiki kehidupan melalui minat yang ditumbuhkan.

Berdasarkan defenisi para ahli diatas Kreativitas menjadi hal utama dalam intensi berwirausaha karena adanya kreativitas menjadikan seseorang lebih inovatif untuk menciptakan sesuatu yang baru.

\section{Kaitan Proactive Personality terhadap intensi berwirausaha.}

Brandstatter (2011) mengatakan bahwa kepribadian proaktif memainkan peran dalam menciptakan suatu usaha dan kesuksesan usaha. Kepribadian proaktif dalam niat berwirausaha merupakan perilaku yang dapat mempengaruhi lingkungan sekitar dalam menerapkan suatu usaha. Perilaku diartikan sebagai rangsangan yang menghasilkan sesuatu terhadap lingkungan sekitarnya. Hal ini berarti perilaku akan terwujud apabila terdapat sesuatu yg dihasilkan. Skineer, oleh Notoadmojo (2003)

Berdasarkan defenisi para ahli diatas Proactive Personality sangat memainkan peran yang cukup besar untuk mendorong seseorang lebih aktif dalam intensi berwirausaha. Hal ini sebagai rangsangan untuk meninmgkatkan intensi berwirausaha.

\section{Kaitan Entrepreneurial alertness terhadap intensi berwirausaha.}

Gupta dan Bostrom (2005) mengusulkan hal itu kewirausahaan akan secara langsung mempengaruhi aktivitas dalam proses pengambilan keputusan. Dalam salah satu studi terbaru, juga ditemukan bahwa kewaspadaan terhadap ide bisnis mengarah pada tingkat otonomi, inovasi dan proaktif yang jauh lebih tinggi tingkat kecenderungan risiko (Cui et al., 2016).

Berdasarkan defenisi para ahli diatas bisa disimpulkan bahwa Entrepreneurial Alertness menjadikan wirausaha berhati hati dalam menjalankan usaha karena seorang wirausaha harus mencari tau informasi yang berkaitan dengan usahanya sendiri.

Berdasarkan hasil defenisi diatas, rancangan model penelitian ini adalah:

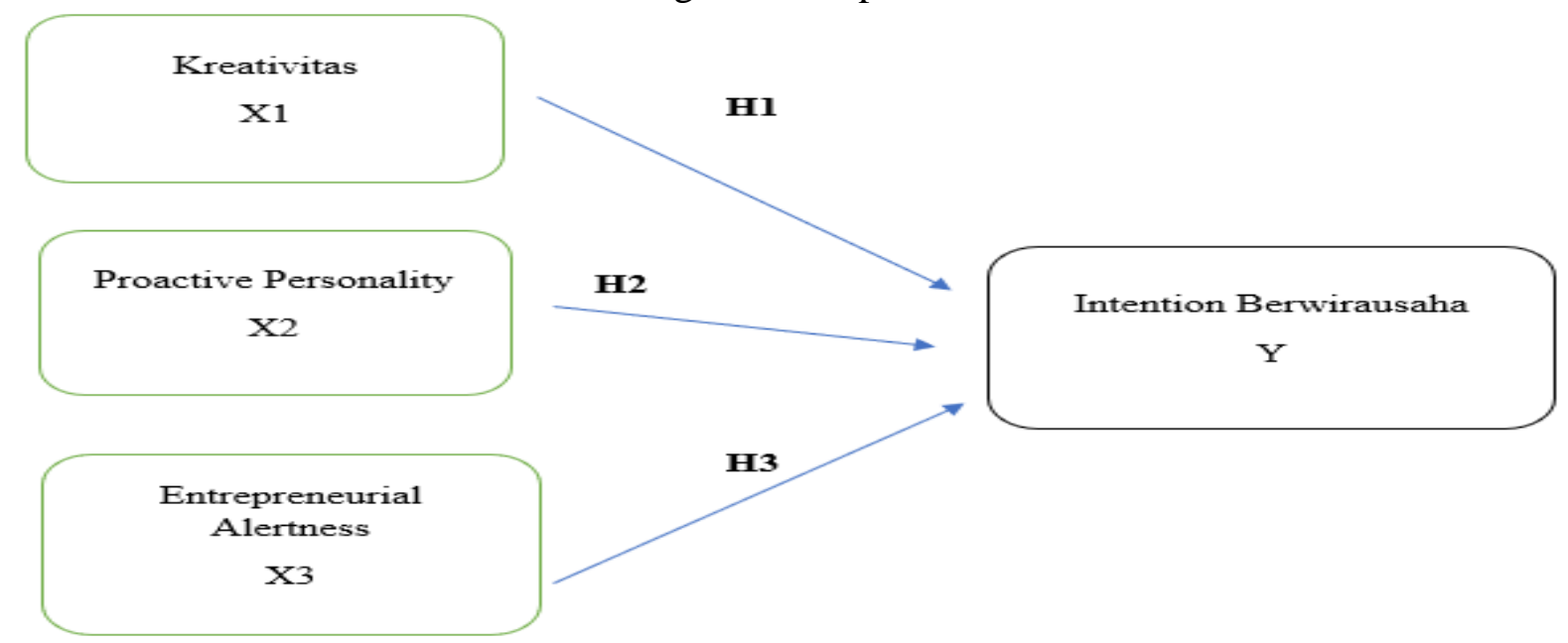

Gambar 1.

Model Penelitian 
Berdasarkan perumusan masalah dan kerangka pemikiran diatas maka dapat disusun hipotesis sebagai berikut :

$\mathrm{H}_{1} \quad$ Kreativitas berpengaruh terhadap Intensi berwirausaha

$\mathrm{H}_{2} \quad$ Proactive Personality berpengaruh terhadap Intensi Berwirausaha

$\mathrm{H}_{3} \quad$ Entrepreneurial Alertness berpengaruh terhadap Intensi berwirausaha

\section{METODOLOGI}

Populasi penelitian adalah mahasiswa universitas tarumanagara. Penelitian ini menggunakan non probability sampling. Jumlah sampel yang digunakan berjumlah 99 responden. Teknik pengumpulan data menggunakan kuisioner yang dibantu dengan Google Form yang disebar melalui media social. Dalam penelitian ini variable yang diteliti meliputi Creativity berjumlah 6 item, Proactive Personality berjumlah 6 item, Entrepreneurial Alertness berjumlah 8 item dan intensi berwirausaha berjumlah 10 item. Pengolahan data dalam penelitian ini menggunakan Sofware SPSS yang menggunakan anilisis regresi berganda.

\section{HASIL ANALISIS DATA}

\section{Uji Validitas} bawah:

Berikut ini hasil uji validitas untuk variabel penelitian dapat dilihat pada tabel di

Tabel 1.

Hasil Uji Validitas Variabel Penelitian

\begin{tabular}{|c|c|c|c|c|c|}
\hline No & Variabel & Pernyataan & rhitung & $\mathbf{r}_{\text {tabel }}$ & Keterangan \\
\hline 1 & \multirow{6}{*}{ Creativity } & Pernyataan 1 & 0,771 & 0,361 & \multirow{6}{*}{ Valid } \\
\hline 2 & & Pernyataan 2 & 0,919 & 0,361 & \\
\hline 3 & & Pernyataan 3 & 0,823 & 0,361 & \\
\hline 4 & & Pernyataan 4 & 0,834 & 0,361 & \\
\hline 5 & & Pernyataan 5 & 0,902 & 0,361 & \\
\hline 6 & & Pernyataan 6 & 0,838 & 0,361 & \\
\hline 1 & \multirow{6}{*}{ Proactive Personality } & Pernyataan 1 & 0,877 & 0,361 & \multirow{6}{*}{ Valid } \\
\hline 2 & & Pernyataan 2 & 0,760 & 0,361 & \\
\hline 3 & & Pernyataan 3 & 0,829 & 0,361 & \\
\hline 4 & & Pernyataan 4 & 0,786 & 0,361 & \\
\hline 5 & & Pernyataan 5 & 0,797 & 0,361 & \\
\hline 6 & & Pernyataan 6 & 0,861 & 0,361 & \\
\hline 1 & \multirow{8}{*}{$\begin{array}{c}\text { Entrepreneurial } \\
\text { Alertness }\end{array}$} & Pernyataan 1 & 0,808 & 0,361 & \multirow{8}{*}{ Valid } \\
\hline 2 & & Pernyataan 2 & 0,902 & 0,361 & \\
\hline 3 & & Pernyataan 3 & 0,709 & 0,361 & \\
\hline 4 & & Pernyataan 4 & 0,791 & 0,361 & \\
\hline 5 & & Pernyataan 5 & 0,868 & 0,361 & \\
\hline 6 & & Pernyataan 6 & 0,820 & 0,361 & \\
\hline 7 & & Pernyataan 7 & 0,779 & 0,361 & \\
\hline 8 & & Pernyataan 8 & 0,715 & 0,361 & \\
\hline 1 & \multirow{9}{*}{ Intensi Berwirausaha } & Pernyataan 1 & 0,793 & 0,361 & \multirow{9}{*}{ Valid } \\
\hline 2 & & Pernyataan 2 & 0,838 & 0,361 & \\
\hline 3 & & Pernyataan 3 & 0,753 & 0,361 & \\
\hline 4 & & Pernyataan 4 & 0,879 & 0,361 & \\
\hline 5 & & Pernyataan 5 & 0,728 & 0,361 & \\
\hline 6 & & Pernyataan 6 & 0,511 & 0,361 & \\
\hline 7 & & Pernyataan 7 & 0,680 & 0,361 & \\
\hline 8 & & Pernyataan 8 & 0,809 & 0,361 & \\
\hline 9 & & Pernyataan 9 & 0,813 & 0,361 & \\
\hline
\end{tabular}




\begin{tabular}{|l|l|c|c|c|c|}
\hline 10 & & Pernyataan 10 & 0,719 & 0,361 & \\
\hline
\end{tabular}

Sumber : Hasil Penelitian, 2020 (Data Diolah)

Berdasarakan tabel di atas menunjukkan bahwa berdasarkan hasil uji validitas untuk seluruh variabel menunjukkan semua nilai $r_{\text {hitung }}$ telah lebih besar dari $r_{\text {tabel }}$ dengan nilai batas minimal korelasi 0,361 sehingga diperoleh hasil bahwa semua pernyataan dalam kuesioner adalah valid.

\section{Uji Reliabilitas} berikut:

Hasil uji reliabilitas untuk setiap variabel dapat dilihat pada tabel di bawah ini sebagai

Tabel 2.

Hasil Pengujian Reliabilitas

\begin{tabular}{|l|c|c|c|}
\hline No & Variabel & Cronbach's Alpha & N of Item \\
\hline 1 & Creativity & 0,919 & 6 \\
\hline 2 & Proactive Personality & 0,901 & 6 \\
\hline 3 & Entrepreneurial Alertness & 0,919 & 8 \\
\hline 4 & Intensi Berwirausaha & 0,911 & 10 \\
\hline
\end{tabular}

Sumber : Hasil Penelitian, 2020 (Data Diolah)

Berdasarkan pada tabel di atas, maka dapat dinyatakan bahwa dari seluruh variabel yang terdiri dari variabel creativity, proactive personality, entrepreneurial alertness, dan intensi berwirausaha memiliki nilai cronbach's alpha di atas 0,6, dengan demikian maka seluruh variabel dapat dikatakan telah reliabel.

Tabel 3.

One-Sample Kolmogorov-Smirnov Test

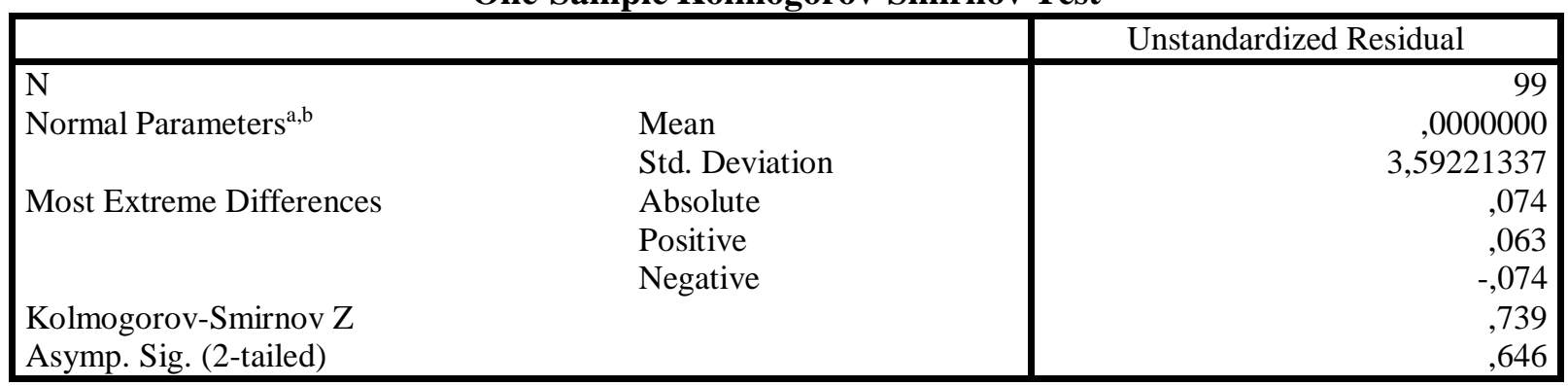

a. Test distribution is Normal.

b. Calculated from data.

Sumber : Hasil Penelitian, 2020 (Data Diolah)

Berdasarkan tabel di atas, dapat dilihat bahwa hasil pengujian normalitas Kolmogorovsmirnov membuktikan bahwa nilai tingkat signifikan yang dihasilkan lebih besar dari 0,1 yaitu sebesar 0,646, dapat disimpulkan bahwa pengujian statistik normalitas tergolong berdistribusi normal.

Hasil untuk pengujian multikolinieritas dapat dilihat pada tabel di bawah:

Tabel 4.

Hasil Pengujian Multikolinieritas

Coefficients $^{\mathrm{a}}$

\begin{tabular}{|c|c|c|}
\hline \multirow[t]{2}{*}{ Model } & \multicolumn{2}{|c|}{ Collinearity Statistics } \\
\hline & Tolerance & VIF \\
\hline $\begin{array}{ll}1 & \text { (Constant) } \\
& \text { Creativity }\end{array}$ & 569 & 1,756 \\
\hline
\end{tabular}




\section{Proactive Personal \\ Entrepreneurial Alertness

Dependent Variabel : Intensi Berwirausaha

Sumber : Hasil Penelitian, 2020 (Data Diolah)

Pada Tabel 4.10 diatas, nilai korelasi untuk seluruh variabel mempunyai nilai tolerance $>0,10$ dan nilai VIF < 10 sehingga dapat disimpulkan bahwa seluruh variabel tidak terdapat masalah dalam multikolinieritas.

Hasil pengujian menggunakan heteroskedastisitas dapat dilakukan dengan menggunakan metode grafik scatterplot yaitu:

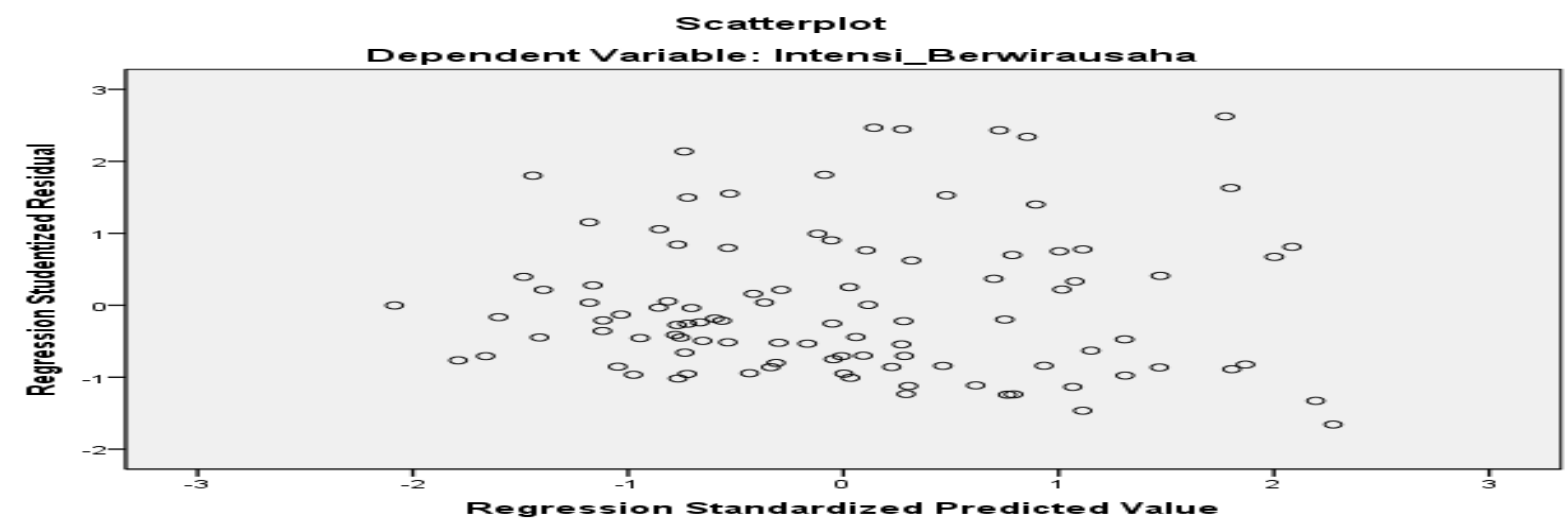

Gambar 2

Grafik Scatterplot

Pada gambar di atas, dapat dilihat bahwa titik-titik grafik Scatterplot menyebar secara acak (random) serta tersebar di atas maupun dibawah angka 0 pada sumbu $\mathrm{Y}$ tanpa membentuk suatu pola tertentu. Hal ini dapat disimpulkan bahwa tidak terjadi heteroskedastisitas.

\section{Pengujian Hipotesis Secara Parsial (Uji t)}

Penentuan dalam menentukan nilai $t_{\text {tabel}}$, maka diperlukan adanya derajat bebas, dengan rumus sebagai berikut :

Rumus : $\mathrm{df}=\mathrm{n}-\mathrm{k}=99-4=95$

Keterangan :

$\mathrm{n}=$ Jumlah Sampel Penelitian

$\mathrm{k}=$ Jumlah Variabel Bebas dan Terikat

Dengan diketahuinya df adalah 96 dan diperoleh nilai tabel tersebut yaitu sebesar 1,660. Sedangkan nilai thitung akan diperoleh dengan menggunakan bantuan program SPSS, kemudian akan dibandingkan dengan nilai $t_{\text {tabel }}$ pada tingkat $\alpha=10 \%$. Hasil uji $t_{\text {hitung }}$ dapat dilihat pada tabel dibawah ini :

Tabel 5.

Hasil Pengujian Parsial (Uji-t)

Coefficients ${ }^{\mathrm{a}}$

\begin{tabular}{|c|c|c|}
\hline Model & $\mathrm{T}$ & Sig. \\
\hline $\begin{array}{ll}1 & \text { (Constant) } \\
& \text { Creativity }\end{array}$ & $\begin{array}{r}, 792 \\
5,561\end{array}$ & $\begin{array}{l}, 430 \\
, 000\end{array}$ \\
\hline
\end{tabular}




\section{Proactive Personal}

Entrepreneurial Alertness

a. Dependent Variable: Intensi Berwirausaha

Sumber : Hasil Penelitian, 2020 (Data Diolah)

Pada variabel creativity $\left(\mathrm{X}_{1}\right)$ terlihat bahwa nilai thitung $(5,561)>\mathrm{t}_{\text {tabel }}(1,660)$ dengan tingkat signifikan $0,000<0,1$, sedangkan variabel proactive personal $\left(\mathrm{X}_{2}\right)$ terlihat bahwa nilai $t_{\text {hitung }}(3,960)>t_{\text {tabel }}(1,660)$ dengan tingkat signifikan $0,000<0,1$ dan variabel entrepreneurial alertness $\left(\mathrm{X}_{3}\right)$ terlihat bahwa nilai $\mathrm{t}_{\text {hitung }}(3,770)>\mathrm{t}_{\text {tabel }}(1,660)$ dengan tingkat signifikan 0,000 $<0,1$ sehingga dapat disimpulkan bahwa terdapat pengaruh positif yang signifikan secara parsial antara variabel creativity, proactive personal dan entrepreneurial alertness terhadap intensi berwirausaha.

\section{Uji Koefisien Determinasi $\left(\mathbf{R}^{2}\right)$}

Hasil dari pengujian untuk koefisien determinasi dapat dilihat pada tabel dibawah :

\section{Tabel 6.}

\section{Uji Koefisien Determinan $\left(\mathbf{R}^{2}\right)$} Model Summary ${ }^{b}$

\begin{tabular}{|c|r|r|r|r|}
\hline Model & \multicolumn{1}{|c|}{$\mathrm{R}$} & \multicolumn{1}{|c|}{ R Square } & Adjusted R Square & Std. Error of the Estimate \\
\hline 1 &, $808^{\mathrm{a}}$ &, 654 &, 643 & 3,648 \\
\hline
\end{tabular}

a. Predictors:, Entrepreneurial Alertness, Proactive Personal, Creativity

b. Dependent Variable: Intensi Berwirausaha

Sumber : Hasil Penelitian, 2020 (Data Diolah)

Berdasarkan tabel hasil pengujian koefisien determinan diatas, dapat dilihat Nilai Adjusted $R$ Square yang diperoleh sebesar 0,643 artinya variabel intensi berwirausaha dapat dijelaskan oleh variabel creativity, proactive personal, dan entrepreneurial sebesar 64,3\% sedangkan sisanya $35,7 \%$ dipengaruhi oleh faktor-faktor lain yang berasal dari luar model penelitian ini seperti lingkungan keluarga, pendidikan, motivasi, semangat dan lainnya.

\section{DISKUSI}

Berdasarkan hasil penelitian yang telah dilakukan maka dalam pembahasan ini peneliti akan membahas mengenai pengaruh creativity, proactive personal dan entrepreneurial alertness terhadap intensi berwirausaha.

\section{Pengaruh Creativity Terhadap Intensi Berwirausaha}

Berdasarkan hasil pengujian hipotesis dengan menggunakan uji-t, diketahui bahwa variabel creativity berpengaruh positif dan signifikan terhadap intensi berwirausaha. Penelitian ini sejalan berdasarkan penelitian terdahulu yang dilakukan oleh Simone, et al (2012) dimana pada hasil penelitiannya didapatkan bahwa kreativitas memiliki pengaruh terhadap intensi berwirausaha.

\section{Pengaruh Proactive Personality Terhadap Intensi Berwirausaha}

Berdasarkan hasil pengujian hipotesis dengan menggunakan uji-t, diketahui bahwa variabel proactive personal berpengaruh positif dan signifikan terhadap intensi berwirausaha. Sama halnya dengan penelitian yang dilakukan Delle dan Amadu (2015) dimana pada hasil penelitian nya terdapat pengaruh positif dan signifikan antara Proactive Personality terhadap intensi berwirausaha.

\section{Pengaruh Entrepreneurial Alertness Terhadap Intensi Berwirausaha}


Berdasarkan hasil pengujian hipotesis dengan menggunakan uji-t, diketahui bahwa variabel entrepreneurial alertness berpengaruh positif dan signifikan terhadap intensi berwirausaha. Penelitian ini juga sejalan berdasarkan penelitian terdahulu yang dilakukan oleh Lim, et al (2017)dimana pada hasil penelitiannya didapatkan bahwa entrepreneurial alertness memiliki pengaruh terhadap intensi berwirausaha.

\section{Pengaruh Creativity, Proactive Personal dan Entrepreneurial Alertness Terhadap Intensi Berwirausaha}

Berdasarkan hasil pengujian hipotesis dengan menggunakan uji koefisien determinasi, diketahui bahwa variabel creativity, proactive personal, entrepreneurial alertness berpengaruh positif dan signifikan terhadap intensi berwirausaha. Besarnya kontribusi yang diberikan oleh variabel creativity, proactive personal, dan entrepreneurial terhadap intensi berwirausaha adalah sebesar $64,3 \%$ sedangkan sisanya $35,7 \%$ dipengaruhi oleh faktor-faktor lain yang berasal dari luar model penelitian ini seperti lingkungan keluarga, pendidikan, motivasi, semangat dan berbagai variabel lainnya.

\section{KESIMPULAN}

Kesimpulan yang diberikan dari penelitian ini adalah sebagai berikut:

1. Creativity berpengaruh positif terhadap intensi berwirausaha pada mahasiswa Universitas Tarumanagara.

2. Proactive personality berpengaruh positif terhadap intensi berwirausaha pada mahasiswa Universitas Tarumanagara.

3. Entrepreneurial Alertness berpengaruh positif terhadap intensi berwirausaha pada mahasiswa Universitas Tarumanagara.

\section{Keterbatasan dan Saran}

\section{Keterbatasan}

Penelitian ini telah dilaksanakan dan diusahakan dapat sesuai dengan prosedur yang ditetapkan namun penelitian ini masih memiliki keterbatasan dalam kuesioner yang memungkinkan responden tidak menunjukkan kondisi yang semestinya sesuai dengan pernyataan yang diajukan dan juga peneliti tidak dapat mengontrol para responden yang memungkinkan tidak jujur dalam menjawab butir-butir pernyataan yang diajukan dalam kuesioner.

\section{Saran}

Berdasarkan hasil dari pembahasan dan kesimpulan dalam penelitian yang telah dilakukan, maka penulis memiliki saran terhadap analisis yang telah dilakukan yaitu sebagai berikut:

a) Diharapkan agar Universitas dapat meningkatkan kreativitas mahasiswa dengan berbagai pendidikan yang diberikan dan tidak hanya berdasarkan pendidikan teori saja tetapi juga dapat melalui berbagai cara seperti pelatihan dan program praktek untuk menciptakan sesuatu yang baru dengan kreativitas mereka sehingga mereka akan mendapatkan pengalaman yang baik ketika ingin memulai usaha mereka sendiri.

b) Diharapkan agar Universitas dapat selalu meningkatkan insiatif mahasiswa dan meningkatkan kemampuan mereka sehingga akan memudahkan mereka dalam memulai usaha mereka sendiri.

c) Bagi peneliti selanjutnya diharapkan bisa menambha variable yang lebih luas lagi untuk mengetahui factor yang mempengaruhi intensi dalam berwirausaha. 


\section{DAFTAR PUSTAKA}

Aurilia Triani Aryaningtyas (2018) "Dukungan Akademik: Moderasi hubungan Kepribadian Proaktif terhadap niat kewirausahaan mahasiswa" Media Ekonomi dan Manajemen, Vol. 33 No. 2, Juli 2018, 175-186

Baldacchino. 2008. "Entrepreneurial Creativity and Innovation", The First International Conference on Strategic Innovation and Future Creation, University of Malta, Malta.

Covey, Steven R. (2010). The 7 Habits of Highly Effective People (7 Kebiasaan Manusia yang Sangat Efektif). Tangerang: Binarupa Aksara Publisher.

Crant, J.M., 2000. Proactive Behavior in Organizations. Journal of Management, 26(3), pp.435-462.

Delle Eric dan Amadu Ibrahim Monipaak (2015) “Proactive Personality and Entrepreneurial Intention: Employment Status and Student Level As Moderators" International Journal of Small Business and Entrepreneurship Research Vol.3, No.4, pp.1-13, July 2015

Dufays, F. (2014), "Creativity and entrepreneurship: changing currents in education and public-life", International Journal of Entrepreneurial Behavior \& Research, Vol. 20 No. 3, pp. 197-199.

Fatmawati, I. (2013). Pengaruh Kreativitas Berwirausaha dan Prestasi Belajar Kewirausahaan Terhadap Motivasi Berwirausaha Pada Mahasiswa Program Studi Pendidikan Akuntansi Fakultas Keguruan dan Ilmu Pendidikan Universitas Muhammadiyah Surakarta Angkatan 2010/2011. Nas

Hapsah Riqki dan Savira Siti Ina (2015) "Hubungan Antara Self Efficacy dan Kreativitas dengan Minat Berwirausaha" Jurnal Psikologi Teori dan Terapan 5(2):80 DOI: 10.26740/jptt.v5n2.p80-89

$\mathrm{Hu}$, Wang, Zhang dan Bin (2018) "Creativity, Proactive Personality, and Entrepreneurial Intention: The Role of Entrepreneurial Alertness" Front. Psychol., vol 9

Kaufman, J. (2016), “The creative construct”, RSA: 21 st Century Enlightenment No. 1, pp. 2427.

Lee, S.H. \& Wong, P.K. 2004. An Exploratory Study of Technopreneurial Intentions: A Career AnchorPerspective. Journal of Business Venturing, 19(1): 7-28.

Lim, Yusof and Nor (2017) "The impact of Entrepreneurial Alertness on Entrepreneurial Intention among University Student in Malaysia: Theory of Planned Behaviour", Journal of Engineering and Applied Sciense 12(6): 1409-1418, Medwell Journal

Munandar,Utami.(2009). Pengembangan kreativitas anak berbakat. Jakarta:Rineka cipta.

Mustafa, M.J., Hernandez, E., Mahon, C. and Chee, L.K. (2016), "Entrepreneurial intentions of university students in an emerging economy: the influence of university support and proactive personality on students' entrepreneurial intention", Journal of Entrepreneurship in Emerging Economies, Vol. 8 No. 2, pp. 162-179.

Notoatmodjo, Soekidjo, 2003, Pengembangan Sumber Daya Manusia, Jakarta: PT. Rineka Cipta.

Phipps, Simone T.A dan College Macon Stage (2012) “ Contributor To An Enterprising Gender: Examining The Influence of Creativity on Entrepreneurial Intentions and The Moderating Role of Political Skill Controlling For Gender" , Academy of Entrepreneurship Journal, volume 18, Number 1

Rodhiah et all 2021 "Appliation of the Analyti Hiereahy Proess Method in determining a reative Industry Strategy: Evidene From reative Industry in South Tangerang" PJAE 18 ( 2021) 
Santrock, J, W. (2014). Psikologi Pendidikan Edisi 5 Jilid 1. Jakarta: Salemba Humanika.

Suryana, Kewirausahaan Kiat dan Proses Menuju Sukses, Edisi 4, Jakarta : Salemba Empat, 2013

Tang, J., Kacmar, M. and Busenitz, L. (2012). "Alertness in the pursuit of new opportunities", Journal of Business Venturing, Vol. 27 No. 1, pp. 77-94.

Tung, Lo Choi. 2011. The Impact of Entrepreneurship Education on Entrepreneurial Intention of Engineering Students. City University of Hongkong: Run Run Show Library.

Valliere (2013) "Entrepreneurial Alertness and Paying Attention" Journal of Enterprising Culture 21(01)

Wijaya, Tony, (2007). Kajian Model Empiris Berwirausaha UKM DIY dan Jawa Tengah. Jurnal Manajemen dan Kewirausahaan

Zimmerer, T. W., dan N. W. Scarborough. 2008. Kewirausahaan dan Manajemen Usaha Kecil. 5 ed. Jakarta: Salemba Empat. 